\title{
Development of annual program guidance and counseling in higher education
}

\author{
Fandy Kurniawan*) \\ Universitas Negeri Yogyakarta \\ ${ }^{*}$ Corresponding author, $\equiv$ e-mail: kfandy2016@gmail.com
}

\begin{abstract}
This study aims to develop and determine the feasibility of the annual program of guidance and counseling in higher education. The method used in this research is Research and Development (R \& D) Research and development carried out by adopting the concept of research and development by Borg and Gall. Based on product test using inter-rater agreement models, it is concluded that the product has fulfilled the content validity of 0.76 or can be categorized as valid (good). Furthermore, based on the results of Focus Group Discussion (FGD), it is concluded that the product can be categorized well, but needs to be refined by making improvements given.
\end{abstract}

Keywords: annual program, guidance and counseling, higher education.

How to Cite: Fandy Kurniawan. (2018). Development of annual program guidance and counseling in higher education . Couns-Edu: International Journal of Counseling and Education, 3(3): pp. 108-114. DOI: https://doi.org/10.23916/0020180317130

\section{Introduction}

The era of globalization exposes the whole country to complex and rapid developments and changes. Every component of society within a country, required to race, improve its competence. The global situation makes life more competitive and opens opportunities for anyone to achieve better status and life. The positive impact of global conditions is to encourage individuals to continue to think and improve their ability, and not satisfied with something that is achieved at this time. Correspondingly, globalization has at least three impacts for undergraduate and postgraduate students, (1) influencing career goals, (2) providing insight into ethical and social issues, (3) enhancing self-development (Litzelman et al., 2017, p. 2)

Efforts to bridge these impacts need to be prepared by qualified individuals. One of the main supporters for achieving the goal of individual formation in this case the student is the quality of higher education quality. The quality of higher education is not enough to be done through the transformation of science and technology, but must be supported by the development of the ability of students to process themselves in choosing and making decisions for the achievement of all life goals. Such an ability not only concerns the academic aspect, but also involves non-academic aspects. This is corroborated by Kemer who revealed that in a recent study, students have high needs in academic, relational, emotional, and career issues (Kemer \& Myers, 2011, p. 114)

Academic aspects can be established by developing curriculum applied in the higher education, while non-academic aspects are the responsibility of the Guidance and Counseling Service Unit (ULBK). Gladding revealed that the counseling unit at higher education should be able to understand how students learn, grow, and grow (Gladding, 2015, p. 500). In addition Gibson and Mitchell also revealed that the role of counselors in higher education plays an important role in educational, social, and emotional 
development of students (Gibson \& Mitchell, 2016, p. 105). Both opinions reinforce that the presence of Guidance and Counseling Services Unit (ULBK) is very central in a higher education.

Jing Sun points out: "The significance of guidance in the university contexts from two perspectives, (i) the needs of students, and (ii) development of the university" (Sun \& Yuen, 2012, p. 204). Based on that opinion, it can be concluded that the importance of Guidance and Counseling in higher education is to bridge the needs of students and develop the quality of the higher education. For students, Guidance and Counseling services can help them in optimizing their potential, setting goals and deciding on future career direction. While for higher education, Guidance and Counseling services can help improve the quality of their graduates, thus enhancing the higher education reputation.

Efforts in delivering students to have a healthy self and mental development, through ULBK was not an easy matter. This happens, because students are faced with complex problems. There are some things that students must face when jumping into the world of Higher Education (1) intensified competition, (2) a lot of focus on the future, (3) increasing uncertainty, (4) dependence on technology, (5) stress always haunting (The Jed Foundation and Education Development Center Inc, 2006, pp. 1-2). In line with that opinion, Ruckert points out: "The rank order of problems presented by students at the counseling center is like this: (1) Problems with academic work and achievement. (2) Enquiries about psychotherapy. (3) Problems with academic orientation and motivation. (4) Depression. (5) Problems with learning. (6) Anxieties / Phobias (Rückert, 2015, p. 38). In addition, the problems faced by students when studying at higher education are: (1) Saturation and Laziness, (2) Inability to manage time, (3) Finance, (4) Social environment, (5) Place boarding, (6) Love and promiscuity (Sudarman, 2004, pp. 36-38).

The problems faced by the student, increasingly increasing in number, Rockland-Miller revealed: One of the most notable findings of this study was that increases were reported in 14 of 19 client problem areas. Also notable was that the number of students reporting with depression doubled, the number of suicidal students tripled, and the number of students seeking services after a sexual assault quadrupled (Rockland-Miller \& Eells, 2010, p. 40).

Description of the problem in the discussion above, was found in many neighborhoods of the University of Yogyakarta and Universitas Sebelas Maret Surakarta. One of the students at Sebelas Maret University expressed a deeply depressed feeling. The student has been too busy engaging in non-academic activities that resulted in a financial coffers to sustain life as a student and forget one of his main duties as a student is to make the final assignment, until he unknowingly arrives at the end of the study boundary as a student. While at Universitas Negeri Yogyakarta there are students who have no passion to live after being haunted by feelings of guilt for falling into promiscuity that take him as a sexual criminal. The consequences of such promiscuity lead him to the tremendous anxiety in him. The two real issues, illustrating the complexity of student problems in the field.

Although students are faced with many problems as mentioned above, there are not many students who meet counselors in the Unit Guidance and Counseling Services in each university. Han Sumi points out that despite having mental health problems, most students are reluctant to seek counselors to help solve their problems and only $40 \%$ of students use counseling and guidance services at higher education (Han \& Heo, 2008, p. 2).

In line with this, although counseling services are already available and ready to assist the students, few new students take advantage of the counseling facilities (The Jed Foundation and Education Development Center Inc, 2011, p. 2). This phenomenon can occur, because not yet optimal role and function of guidance and counseling in Higher Education and program of guidance and counseling service in Higher Education, not yet targeting all students.

One effort to finalize the role of ULBK is to develop a comprehensive program of Guidance and Counseling in a comprehensive manner, so that it can be a basic foot in implementing services for students. Efforts to carry out need assessment as a basis for formulating guidance and counseling programs in higher education, required standard and valid instruments. At least in an effort to uncover the needs of students there are 2 valid and valid instruments, namely the Inventori Tugas Perkembangan Perguruan Tinggi (ITP PT) and Alat Ungkap Masalah Umum Perguruan Tinggi (AUM UMUM PT).

The development of an annual program model of guidance and at the Universitas Negeri Yogyakarta and Universitas Sebelas Maret is deemed necessary to be developed, as this annual model of 
guidance and counseling can be an alternative in the process of achieving developmental tasks, which is expected to be an essential tool for life in phase next.

Preparation of an annual program model of guidance and counseling is very important because it is expected to become a reference for Counselors in Higher Education in preparing guidance and counseling programs designed to achieve goals. The purpose of guidance and counseling is to maximize student potential and help address the problems faced by them. Counseling and guidance programs are also being made to help all students develop their potential through the provision of development assistance and special assistance to individuals regarding personal, social, career, or other unique educational needs (Gysbers \& Henderson, 2014, p. 140).

In product development, in this case the annual model of guidance and counseling needs-based, researchers expect specifications and product details to be developed, including as follows:

1. The annual program of guidance and counseling will be prepared based on the needs of the students.

2. The annual program of guidance and counseling, prepared based on measurement instruments of Inventori Tugas Perkembangan Perguruan Tinggi (ITP PT) and Alat Ungkap Masalah Umum Perguruan Tinggi (AUM UMUM PT). to support the need assessment process.

3. Guidance and counseling programs have the following structure: (a) Rationale, (b) Legal Basis, (c) Vision and Mission, (d) Description of Needs, (e) Purpose, (f) Service Area, (g) Action Plan, (h) Theme Development / Topics, (i) Evaluation, reporting and follow-up, (j) Facilities and Infrastructure, (k) Budget.

\section{Method}

Based on the consideration and conformity between the problems, objectives, and research focus, this research uses research and development method or often also called Research and Development ( $R$ \& $\mathrm{D})$. According to Borg and Gall, "educational research and development (R \& D) is a process used to develop and validate educational production." (Borg \& Gall, 1983, p. 772) While Sukmadinata argues that research and development is a process or steps to develop a new product or refine an existing and accountable product (Sukmadinata, 2009, p. 164).

Based on the opinion of some experts above, it can be concluded that research and development or also called Research and Development $(\mathrm{R} \& \mathrm{D})$ is a process to develop a new product and improve the existing old products, and validate the product developed or enhanced.

The reason for choosing the type of research and development or so-called Research and Development $(R \& D)$ is that based on the preliminary study results that have been conducted, it is learned that a lot of problems experienced by students, both academically and socially. In addition, the guidance and counseling services unit at the university still has not developed a standard guidance and counseling program for students. During this counseling and guidance programs in higher education are also less targeted to all students, so many students who have not enjoyed the service program that is implemented by the unit of guidance and counseling services.

There is a series of steps that must be taken in developing a product, namely "research and information collecting, planning, preliminary form of product development, preliminary field testing, main product revision, field testing, operational product revision, operational field testing, final product revision, and dissemination and implementation " (Borg \& Gall, 1983, p. 775).

In developing the model of this program, it will refer to the series of phases proposed by Borg and Gall, but with little modifications to the needs of the study. In this research, program development program which is done is as follows:

1. Conduct a preliminary study to collect information through, (1) Need Assessment, and (2) Formulate the problem.

2. Planning, that is by identifying and defining the model of annual program of guidance and counseling in higher education and the formulation of goals. 
3. Develop the initial product type that is the annual model of guidance and counseling program in higher education

4. Feasibility test, at this stage the initial draft of guidance and counseling program of learning is validated through two stages: theoretical validation and validation of practitioners.

a) Expert validation, the initial draft of the annual model of guidance and counseling courses in higher education will be validated by two theorists to obtain assessment, feedback and suggestions as a revised material of the developed program. The draft model of an annual program of guidance and counseling in a university that has been validated by experts in theory is then revised in accordance with the advice and input of both experts.

b) Validation of practitioners, draft model of annual program of guidance and counseling at higher education that have been revised in accordance with suggestions and input from experts then discussed in the Focus Group Discussion (FGD) forum by practitioners to get qualitative assessment. The draft model of guidance and counseling programs at higher education that have been given input by practitioners is then discussed with a counselor in ULBK for improvement and adjustment of circumstances in the Higher education.

5. Revision of the final product, final product revision is made based on analysis, discussion and input of validation activity result.

6. Final program, final program is a model of guidance and counseling programs in higher education based on the results of validation, discussion, analysis, and revision.

7. Dissemination and Implementation The research and development model of Borg and Gall in the development of guidance and counseling programs in higher education is not carried out until the dissemination and implementation stage of the product due to several considerations including:

a) In terms of time to implement the model of guidance and counseling programs in Higher Education takes a long time that is for six months.

b) Theoretically the research and development as described by Borg and Gall has 10 steps one step at stage four is product validation. Until this stage there has been a product that has been produced but has not been tested its effectiveness. However, the resulting product has been tested its feasibility by validators through theorists and practitioners.

\section{Results and Discussions}

In this section will be described data test results obtained from expert Guidance and Counseling and, prospective users of the product counselors at ULBK Universitas Negeri Yogyakarta and Universitas Sebelas Maret Surakarta. Experimental and Counseling expert test data were obtained from two Guidance and Counseling experts. Test data of prospective users of the product were obtained from two counselors at ULBK Universitas Negeri Yogyakartaand one counselor at ULBK Universitas Sebelas Maret Surakarta.

1. Description of Results of Annual Program Model Development Guidance and Counseling Before Validation

The annual model of guidance and counseling programs at Universitas Negeri Yogyakarta and Sebelas Maret University will be based on the Comprehensive Guidance and Counseling Program according to Norman C. Gysbers. This comprehensive guidance and counseling program has four components, namely: (1) basic services, (2) responsive services, (3) individual planning, (4) system support (Gysbers \& Henderson, 2014, p. 72). The guidance and counseling program has the following structure: (a) Rationale, (b) Legal Basis, (c) Vision and Mission, (d) Description of Requirement, (e) Objective, (f) Service Area, (g) Operational Plan (H) Development of themes / Topics, (i) Evaluation, reporting and follow-up, (j) Facilities and Infrastructures, (k) Budget Costs. The instruments used in this study are the Inventori Tugas Perkembangan Perguruan Tinggi (ITP PT) and Alat Ungkap Masalah Umum Perguruan Tinggi (AUM UMUM PT. In addition, there are drawing attention is all the development process up to the implementation of guidance and counseling program, which is given a touch of technology and information.

2. Exposure Data Validation Test Result

Experimental data obtained through the assessment of acceptability of the annual program model of guidance and counseling at University of Yogyakarta and Universitas Sebelas Maret Surakarta were analyzed quantitatively by using inter-rater aggrement model analysis in order to see the 
reliability level of the guidance based on the assessment of two experts. Data analysis techniques using inter-rater aggrement model (Gregory, 2013) are presented as follows:

\begin{tabular}{|c|c|c|c|}
\hline & & Expe & non 1 \\
\hline & & $\begin{array}{l}\text { Low Relevance } \\
(1-2)\end{array}$ & $\begin{array}{c}\text { High Relevance } \\
\quad(3-4)\end{array}$ \\
\hline Expert & $\begin{array}{l}\text { Low Relevance } \\
\qquad(1-2)\end{array}$ & $\mathbf{A}$ & B \\
\hline 2 & $\begin{array}{l}\text { High Relevance } \\
\qquad(3-4)\end{array}$ & C & D \\
\hline
\end{tabular}

Figure 1. Inter-rater Agreement Model

After the assessment of acceptability of the annual program of guidance and counseling at Universitas Negeri Yogyakarta and Universitas Sebelas Maret Surakarta from the first expert and the second expert was analyzed, the data obtained as follows:

Table 1. Tabulation of Acceptability Assessment Results

\begin{tabular}{lll}
\hline Relevance & Tally & Amount \\
\hline A & - & 0 \\
\hline B & - & 0 \\
\hline C & HIIII & 8 \\
\hline D & MUI IN IINI & 26 \\
\hline
\end{tabular}

Based on the results of the tabulation of acceptability assessment by the first expert and the second expert, then to determine the expert test result index can use the following formula:

$$
\text { Expert Test Index }=\frac{\mathrm{D}}{\mathrm{A}+\mathrm{B}+\mathrm{C}+\mathrm{D}}
$$

By using the formula can be seen that the index of expert test results of 0.76 , it can be concluded that the annual model of guidance and counseling programs at Universitas Negeri Yogyakarta and Universitas Sebelas Maret Surakarta have a high validity or good, because the category of test index validity model annual program of guidance and counseling at Universitas Negeri Yogyakarta and Universitas Sebelas Maret Surakarta conducted by the expert refers to the classification of validity put forward by Guilford (1956), namely: $0.80<\mathrm{rxy} \leq 1.00$ is categorized as having very high (very good) validity, $0,60<\mathrm{rxy} \leq 0.80$ is categorized as having high validity (good), $0.40<\mathrm{rxy} \leq 0.60$ is categorized as having moderate (moderate) validity, $0.20<\mathrm{rxy} \leq 0.40$ is categorized as having low validity (less), 0,00 $<\mathrm{rxy} \leq 0.20$ is categorized as having very low validity (ugly), and $\mathrm{rxy} \leq 0,00$ is categorized as invalid.

Although the overall model of guidance and counseling programs at higher education that have been developed as a whole has been considered feasible, experts and practitioners continue to offer suggestions and criticisms that can be used to improve the model of the annual guidance and counseling program at higher education.

. The validation results of this annual model of guidance and counseling program developed, further strengthened with the results of previous research. Among the research conducted by Luky Kuriawan entitled "Development of Comprehensive Guidance and Counseling Services Program in SMA". The research uses standard instruments to reveal the needs of high school students, to be used by teachers of counseling and counseling in the high school. The results obtained an assessment of 81.96 and based on defined effectiveness criteria included in either category or eligible to be implemented (Kurniawan, 2015, pp. 1-3). 
Furthermore there is research from Hardi Santosa. The study is entitled "Personal Social Counseling and Counseling Program to Develop Sexual Behavior of Adolescent Health (Development Study In High School Sma Kartika Siliwangi 1 Bandung)". This study aims to produce a program of personal social counseling and counseling from the results of need assessment which aims to develop students' healthy sexual behavior. The results of the study showed: (1) in general the student's sexual behavior is at the level of alert towards the need for development; (2) the handling of student sexual behavior problems is carried out with responsive service with reactive sporadic approach; (3) guidance and counseling program at SMA Kartika Siliwangi 1 Bandung has not yet used a new paradigm of comprehensive guidance and counseling with prevention and development approach; (4) Personal-social guidance and counseling programs to develop healthy sexual behavior of adolescents refers to comprehensive counseling and counseling with a prevention and development-oriented approach; and (5) personal-social counseling and counseling programs have proven to be effective in developing healthy student sexual behavior. (Santosa, 2013, pp. 1-3).

Based on the above explanation, including exposure of the validation test of the annual program model of guidance and counseling and the results of previous research, making the model of the annual program of guidance and counseling at Universitas Negeri Yogyakarta and University Sebelas Maret Surakarta become more stable and fit to be used as a reference for counselors at UPT LBK University in carrying out guidance and counseling services.

\section{Conclusions}

This research and development has resulted in the product of an annual program model of guidance and counseling in higher education. This product is developed in order to be used as an annual model of Guidance and Counseling which is prepared based on the instrument need assessment that has been standard and valid. So it is expected to be a reference for ULBK counselors in providing optimal service for students. The process for producing this product can be explained as follows:

1. Expert test results concluded that the product has fulfilled the content validity of 0.76 or can be categorized valid (good). The product is enhanced by making improvements from some of the criticisms and suggestions provided by experts.

2. Focus Group Discussion (FGD) results from practitioners concluded that the product can be categorized well. According to the assessment of ULBK counselor of Universitas Negeri Yogyakarta and Universitas Sebelas Maret Surakarta as practitioners, it is concluded that the product can be categorized well, but needs to be refined by making improvements given by practitioners until the final product is ready for use.

\section{References}

Borg, W. R., \& Gall, M. D. (1983). Educational research: An introduction. Longman Publishing.

Gibson, R. L., \& Mitchell, M. H. (2016). Bimbingan dan konseling. Pustaka Pelajar.

Gladding, S. (2015). Konseling: Profesi Menyeluruh (alih Bahasa oleh Winarno dan Lilian Yuwono). Indeks, Ed.). Jakarta.

Gregory, R. J. (2013). Tes Psikologi Sejarah, Prinsip, dan Aplikasinya. Jakarta: Penerbit Erlangga.

Gysbers, N. C., \& Henderson, P. (2014). Developing and managing your school guidance and counseling program. John Wiley \& Sons.

Han, S., \& Heo, J. (2008). Career Counseling on Campus in South Korea. Career Planning \& Adult Development Journal, 24(4), 57-64. Retrieved https://ezp.lib.unimelb.edu.au/login?url=https://search.ebscohost.com/login.aspx?direct=true\&db $=\mathrm{ehh} \& \mathrm{AN}=44007862 \&$ site $=$ eds-live $\&$ scope $=$ site

Kemer, G., \& Myers, J. E. (2011). Application of Developmental Counseling and Therapy to Turkish college students. Procedia - Social and Behavioral Sciences, 30, 1153-1160. https://doi.org/10.1016/j.sbspro.2011.10.225

Kurniawan, L. (2015). Pengembangan Program Layanan Bimbingan Dan Konseling Komprehensif Di Sma. | Jurnal Psikologi Pendidikan \& Konselin, 1(1), 1-8.

Litzelman, D. K., Gardner, A., Einterz, R. M., Owiti, P., Wambui, C., Huskins, J. C., ... Umoren, R. A. (2017). On Becoming a Global Citizen: Transformative Learning Through Global Health 
Experiences. Annals of Global Health. https://doi.org/10.1016/j.aogh.2017.07.005

Rockland-Miller, H. S., \& Eells, G. T. (2010). The Implementation of Mental Health Clinical Triage Systems in University Health Services. Journal of College Student Psychotherapy, 20(4), 39-51. https://doi.org/10.1300/J035v20n04_05

Rückert, H.-W. (2015). Students' mental health and psychological counselling in Europe. Mental Health \& Prevention, 3(1-2), 34-40. https://doi.org/10.1016/j.mhp.2015.04.006

Santosa, H. (2013). Program Bimbingan dan Konseling Pribadi Sosial untuk Mengembangkan Perilaku Seksual Sehat Remaja. Universitas Pendidikan Indonesia, 2(1).

Sudarman, P. (2004). Belajar efektif di perguruan tinggi. Bandung: Simbiosa Rekatama.

Sukmadinata, N. S. (2009). Metode penelitian pendidikan. Program Pascasarjana Universitas Pendidikan Indonesia dengan PT Remaja Rosdakarya.

Sun, V. J., \& Yuen, M. (2012). Career Guidance and Counseling for University Students in China. International Journal for the Advancement of Counselling, 34(3), 202-210. https://doi.org/10.1007/s10447-012-9151-y

The Jed Foundation and Education Development Center Inc. (2006). 2006 mtvU College Mental Health Study: Stress, Depression, Stigma \& Students. Retrieved September 26, 2017, from http://cdn.halfofus.com/wp-content/uploads/2013/10/2006-mtvU-College-Mental-Health-StudyExecutive-Summary-Final.pdf

The Jed Foundation and Education Development Center Inc. (2011). Campus Mental Health Action Planning. Retrieved September 25, 2017, from https://www.jedfoundation.org/wpcontent/uploads/2016/07/campus-mental-health-action-planning-jed-guide.pdf 